\title{
Sleutelen aan de voeding
}

Citation for published version (APA):

Saris, W. H. M. (1989). Sleutelen aan de voeding. Rijksuniversiteit Limburg. https://doi.org/10.26481/spe.19890120ws

Document status and date:

Published: 20/01/1989

DOI:

10.26481/spe.19890120ws

Document Version:

Publisher's PDF, also known as Version of record

\section{Please check the document version of this publication:}

- A submitted manuscript is the version of the article upon submission and before peer-review. There can be important differences between the submitted version and the official published version of record.

People interested in the research are advised to contact the author for the final version of the publication, or visit the DOI to the publisher's website.

- The final author version and the galley proof are versions of the publication after peer review.

- The final published version features the final layout of the paper including the volume, issue and page numbers.

Link to publication

\footnotetext{
General rights rights.

- You may freely distribute the URL identifying the publication in the public portal. please follow below link for the End User Agreement:

www.umlib.nl/taverne-license

Take down policy

If you believe that this document breaches copyright please contact us at:

repository@maastrichtuniversity.nl

providing details and we will investigate your claim.
}

Copyright and moral rights for the publications made accessible in the public portal are retained by the authors and/or other copyright owners and it is a condition of accessing publications that users recognise and abide by the legal requirements associated with these

- Users may download and print one copy of any publication from the public portal for the purpose of private study or research.

- You may not further distribute the material or use it for any profit-making activity or commercial gain

If the publication is distributed under the terms of Article $25 \mathrm{fa}$ of the Dutch Copyright Act, indicated by the "Taverne" license above, 


\section{SLEUTELEN AAN DE VOEDING}

Rede uitgesproken bij de aanvaarding van het ambt van gewoon hoogleraar in de Biologische Gezondheidkunde in het bijzonder de Voeding aan de Rijksuniversiteit Limburg te Maastricht op 20 januari 1989 door Prof. Dr. Ir. Wim H.M. Saris. 
mijnheer de rector

zeer geachte toehoorders

Het is ca. 15 jaar geleden dat tijdens de uitreiking van de jaarprijs voor voedingsvoorlichting, Prof. Cees Den Hartog, mijn zeer gewaardeerde leermeester van het eerste uur ,een inleiding hield onder de veelzeggende titel "VR-ETEN OM TE LEVEN" Hij vroeg zich daarbij het volgende af; "Wie is zich nog bewust warneer hij aan de maaltijd zit of een snack gebruikt, dat eten in de eerste plaats dient om te leven". Meestal realiseren we ons of het lekker smaakt en dat we daarom teveel hebben gegeten.

Dat eten in de eerste plaats dient om te leven wordt men zich pas bewust als er een tekort aan voedsel ontstaat. Een situatie die alleen de ouderen onder ons zich nog levendig kunnen voorstellen.

Vaak wordt men zich pas pijnlijk bewust van deze relatie wanneer er problemen zijn met de gezondheid. De mededeling van de arts dat men lijdt aan een of andere kwaal heeft tot gevolg dat mensen beginnen te sleutelen aan hun voeding. Op dergelijke momenten wordt voeding iets dat een directe relatie heeft met een gezond leven. 
Ik wil het vandaag niet met $u$ hebben over deze vormen van sleutelen aan de voeding. In het algemeen gaat het hierbij om een mengeling van subjectieve en objectieve argumenten en vaak ook gevoelens die uiteindelijk leiden tot een verandering in het voedingsgedrag.De inhoud van mijn rede heeft betrekking op de wetenschap over de relatie lussen voeding en gezondheid en in het bijzonder de mogelijkheden en onmogelijkheden om met de vergaarde kennis te sleutelen aan onze voeding. Een proces dat moet leiden tot verbetering of behoud van de gezondheid.

In relatie to ziekte gaat het in de eerste plaats om de therapeutische mogelijkheden om door middel van aanpassingen in de voeding te komen tot een herstel. We spreken in een dergelijke situatie van een dieet, afgeleid van het Griekse "DIAITA" , wat zoveel betekent als leefwijze. Dit geeft in feite al aan dat het niet simpel gaat om een voedingskuurtje van 10 dagen om het probleem op te lossen. Veeleer dient er sprake te zijn van langdurige veranderingen in het voedingsgedrag. Dat dit een verre van gemakkelijke taak is, daarop wil ik later in mijn betoog nog ingaan.

In relatie tot het gezonde bestaan gaat het vooral om het 
identificeren en elimineren van die factoren in de voeding welke deze situatie bedreigen. Ook hierbij gaat het om veranderingen die blijvend in het normale leefpatroon ingebouwd dienen te worden. Veranderingen die alleen maar een kans van slagen hebben als men ze als normale voeding beschouwd en zeker niet iets wat mogelijk wel zeer gezond is maar waarbij gelijktijdig de neus dicht gehouden dient te worden. Een aureool dat vaak ten onrechte nog rond het dieet hangt.

Ik zal trachten aan de hand van voorbeelden een en ander te verduidelijken. Deze voorbeelden zijn niet willekeurig gekozen maar hebben grotendeels te maken met de energiestofwisseling.

De reden hiertoe is tweeledig. Enerzijds wil ik hiermee het bijzondere karakter van deze dag accentueren; nl. de uitreiking van de Peter Debye prijs aan Margaret Dauncey en Andrew Prentice voor hun belangrijke werk op het gebied van de energiestofwisseling en anderzijds geeft het me de gelegenheid ideen en resultaten uit het hoofdproject Voeding te presenteren, gezien het feit dat een belangrijk deel van ons onderzoek op het gebied van de energiehuishouding van het menselijk lichaam is geconcentreerd. 


\section{Normen en waarden}

Hoewel Voeding algemeen beschouwd wordt als een jonge wetenschap zijn de fundamenten, zeker wanneer we het hebben over de energiewisseling, reeds gelegd in het begin van de 17 e eeuw. Het was de bekende fysioloog Sanctorius die, zittend in een gigantische waag, voedsel tot zich nam en daaruit de eerste grondbeginselen van de energiestofwisseling destileerde en beschreef. Vlak voor de Franse Revolutie, nu 200 jaar geleden, waren het Lavoisier en de fysicus Laplace die voor het eerst de warmteproductie bij proefdieren kwantificeerden. In zijn brieven aan de Franse academie van wetenschappen beklaagde Lavoisier zich er overigens over dat hij weinig experimenten had kunnen uitvoeren omdat door de zachte winter het noodzakelijke ijs weinig voor-handen was geweest. Wat dat betreft is er weinig veranderd; wetenschappers blijven klagen over gebrek aan middelen.

In de 19e eeuw ontrafelden geleerden als Reynault in Parijs en Voigt en Pettenkofer in München het belang van de energie-leverende voedingsstoffen eiwitten, vetten en koolhydraten, voor het instandhouden van het leven. De 
lange reeks van ontdekkingen, die door Heymans uit Groningen omschreven werd als "een lange St. Nicolaasavond" deed rond de eeuwwisseling een stemming ontstaan als zou het meeste op het gebied van de voeding nu wel gedaan zijn. Slechts de invulling van de details zou nog wat tijd kosten. Toch bleek toen al dat synthetisch samengestelde dieten met de bekende voedingsstoffen voor proefdieren onvoldoende waren om in leven te blijven.

De ontdekking van de vitaminen aan het begin van deze eeuw, waaraan Nederlandse geleerden een belangrijke bijdrage hebben geleverd, gaf een nieuwe impuls aan het voedingsonderzoek. Het ontrafelen van allerlei deficientieziekten heeft ertoe geleid dat wij thans aanbevelingen doen voor zo'n dertigtal voedingsstoffen, die in adequate hoeveelheden in onze voeding dienen te zitten om gezond te blijven. En het einde is wat dat betreft nog niet in zicht.

Met het toenemende aantal vitale stoffen werd ook de roep binnen de gezondheidszorg om deskundigen die voedingen konden samen-stellen en berekenen groter. Reden waarom in 1935 de eerste dietetiek opleiding van start ging.

In de periode na de tweede wereldoorlog werd het steeds duidelijker dat we niet alleen problemen kunnen 
verwachten van een tekort aan bepaalde stoffen maar dat een teveel evenzeer de gezondheid schaadt. Het ongebreidelde optimisme heeft plaats gemaakt voor een realisme dat er nog een lange weg te gaan is.

Dat het daarbij vaak bijzonder moeilijk is om grenzen te trekken moge blijken uit het volgende voorbeeld.

Dat een te grote energieopname leidt to overgewicht is een gegeven dat weinigen nog in twijfel trekken. Wanneer we daarbij grenzen kunnen trekken tussen wat we nog als een normaal gewicht beschouwen en waar duidelijk sprake is van overgewicht is het ook nog mogelijk om de kaders aan te geven voor een gewenste energie-aanbeveling. Moeilijker wordt het, zo niet onmogelijk, wanneer we in dit normale gebied de resultaten betrekken van onderzoek naar de relatie tussen levensduur en energieopname van proefdieren.

Vanaf het dertigste levensjaar voltrekt de achteruitgang van ons leven zich in vlot tempo wat gepaard gaat met talloze veranderingen zoals rimpels, grijs haar en een verminderde weerstand tegen ziekte. Onderzoek van onder meer Ross en Bras laat zien dat wanneer men bij proefdieren de energetische waarde - en niet de voedingswaarde - van de voeding terugbrengt tot ca $70 \%$ 
van wat als normaal beschouwd wordt voor deze dieren, de gemiddelde levensduur aanzienlijk verlengd. wordt. Maar dat niet alleen, het blijkt dat deze methusalemratten ook nog ouder worden met minder ziekten, tumoren en andere afwijkingen. Wel zijn ze wat kleiner van formaat.

Wanneer we deze gegevens bekijken in het licht van het huidige voedingspatroon in de westerse wereld met de nog steeds toenemende groei in de lengte, de zogenaamde seculaire trend, dan vervagen termen als normaal of optimaal en kunnen we alleen nog met zekerheid vaststellen dat de extremen in het traject van energie opname leidt tot een verslechtering van de gezondheidstoestand.

In dit verband zijn de gegevens interessant, die door de antropologen Eaton en Konner zijn verzameld over onze verre voorouders uit het stenen tijdperk zo'n 40.000 jaar geleden, in een periode voordat enige vorm van landbouw of voedselbewerking zijn intrede had gedaan.

Op basis van voedingsonderzoek bij meer dan 50 verschillende primitieve gemeenschappen en informatie over skeletsamenstelling en vondsten van voedselresten als zaden en botten van dieren, komen zij tot een schatting van de samenstelling van de voeding van de toenmalige Homo sapiens. 
Belangrijkste variabele in de voedselopname was daarbij het aandeel in thet voedselpakket van dierlijke of plantaardige oorsprong.

Berekeningen laten zien dat een verschuiving naar bijvoorbeeld meer dierlijke produkten leidt tot de opname van meer eiwit ten koste van koolhydraten. Echter het aandeel aan vet blijft vrijwel onveranderd laag; ongeveer 20 tot maximaal $25 \%$ van de energieopname. Dit is een opmerkelijk verschil met het huidige voedingspatroon waar vet voor ruim $40 \%$ tekent.

Dit grote verschil wordt voornamelijk veroorzaakt door het verschil in vetheid van vlees van de tegenwoordige landbouwhuisdieren met een carcasanalyse van 30 a $40 \%$ vet t.o.v. het in het wild levende dieren met een vetgehalte van minder dan $5 \%$.

Er waren nog meer interessante verschillen zoals een veel hogere opname van onverzadigde vetten ten opzichte van verzadigde vetten, de z.g. P/S ratio, de grotere hoeveelheid aan ruw vezel en een lage natriumopname. Maar daarnaast ook overeenkomsten zoals een hoge eiwit en calciumopname. Bespreking daarvan zou echter te veel tijd vergen.

Deze informatie stemt tot nadenken over de huidige 
wetenschappelijke inzichten en kennis betreffende de dagelijkse gewenste opname van energie en voedingsstoffen. Het kan in ieder geval ais een soort van waarschuwing gelden om niet al te dogmatisch om te gaan met voedingsnormen. Is bijvoorbeeld een dergelijk lage vetconsumptie van $20 \mathrm{En} \%$ in relatie tot de gezondheid realistisch?

Wanneer we de voedingsadviezen van de meeste westerse landen erop na lezen inclusief het Nederlandse advies van de Voedingsraad, Richtijnen Goede Voeding, dan blijkt daaruit dat men een vetreductie tot 30 à $35 \mathrm{En} \%$ wenselijk acht (3). Wetenschappelijk zijn er echter weinig argumenten in te brengen tegen de veronderstelling dat $20 \mathrm{En} \%$ nog beter is. De realiteit leert ons echter dat met het huidige aanbod van voedingsmiddelen een dergelijke norm nauwelijks haalbaar is. Alleen met behulp van een, in onze ogen, zeer extreem dieet is zoiets realiseerbaar. Zelf hebben we een aantal jaren geleden een groep personen gevonden die een dergelijk lage vetopname hadden. Het waren wielrenners die meededen aan de Tour de France. Hun voedselkeuze is gericht op een maximale energieopname in de vorm van koolhydraten en eiwit om dagelijks als eerste de finish te halen, maar ik kan u verzekeren dat er behoorlijk aan de 
voeding gesleuteld was om dit streven te bereiken (4). Op zichzelf is het overigens interessant dat juist deze groep. waar extreme fysieke prestatie zo belangrijk is, een voeding tot zich neemt welke veel overeenkomst vertoont met die van de prehistorische mensen die waarschijnlijk ook een behoorlijke inspanning moesien verrichten om hun dagelijkse kost te verzamelen.

Uit het voorafgaande zal duidelijk zijn geworden dat de huidige aanbevelingen een mengeling is van wetenschappelijke inzichten maar dat de tijdsgeest en het aanbod aan voedingsmiddelen daarbij een niet te onderschatten rol spelen. Het belekent ook dat de voeding waarvan nu de voorlichting gesteld word dat het een gezonde is, straks toch wellicht weer wat gewijzigd moet worden. Reden waarom we met de grootst mogelijke voorzichtigheid nieuwe wetenschappelijke bevindingen aan een groter publiek kenbaar dienen te maken. Helaas gebeurt het de laatse tijd maar al te vaak dat feiten, hoe juist op zich zelf ook, te snel via de media bereiken en leiden tot conclusies dat er weer gesleuteld dient te worden aan de voeding. Ik ga dan nog maar voorbij aan de vele boude beweringen die de krant halen en die nergens op gebaseerd zijn. Op zich zelf is 
het overigens een verheugend feit dat de consument zich steeds meer bewust is van de relatie voeding en gezondheid en dat hij of zij wil weten hoe een verantwoorde voeding is samen te stellen uit de grote hoeveelheid voedingsmiddelen die gekozen kunnen worden.

Het geeft tevens aan dat men in principe geinteresseerd is om veranderingen aan te brengen. De vraag is echter wanneer en op welke wiize het moge lijk is om verantwoord aan de voeding te sleutelen.

Verantwoord kan het alleen zijn wanneer een verandering in voedingsgedrag of het volgen van een dieet ook daadwerkelijk de beoogde verbetering van de gezondheid tot gevolg heeft of voorkomt dat de situatie verslechtert. Kortom hoe effectief is het dieet.

De vraag, wanneer, lijkt op het eerste gezicht een overbodige toevoeging. Zodra de diagnose eenmaal gesteld is kan gestart worden met de therapie. Het maken van keuzes is echter allerminst eenvoudig. Reden waarom binnen de geneeskunde een meer gestructureerde benadering van het nemen van beslissingen snel aan waarde wint. Door het besluitvormingsproces te structureren en vervolgens binnen de geschetste structuur de alternatieve keuzemogelijkheden tegen elkaar af te wegen kan men 
bijvoorbeeld afleiden welke therapeutische strategièn onder de gegeven omsiandigheden optimaal zijn. Binnen de dietetiek is er aan dit aspect nog weinig aandacht besteed. Een dergelijke manier van werken zal zeker ook zijn effect hebben op stroom-lijning en standaardisering van het dietistisch handelen.

Tenslotte de wijze waarop er gesleuteld dient te worden. Dit is zonder iwijfel het moeilijkste aspect. Globaal zijn er twee benaderingswijzen: De betreffende persoon of groep van personen een betere eetgewoonten aanleren op basis van het huidige aanbod aan voedingsmiddelen. Dit betekent dat er een verandering in het keuzegedrag dient plaats te vinden. Of zorgen dat aan de aanbodzijde zodanige voedingstechno-logische veranderingen worden aangebracht dat het voedselkeuze-gedrag eigenlijk ongemoeid gelaten kan worden. Uiteraard is een combinatie van beide ook mogelijk. Ik zou graag aan de hand van enkele concrete voorbeelden de drie eerder genoemde aspecten van het sleutelen aan voeding, wanneer, effectiviteit en wijze waarop, in het licht van deze beide strategieën toelichten. 


\section{Dieetadviezen en voeding}

Uit een door het CIVO-TNO onderzochte landelijke steekproef blijkt dat ruim een kwart van de bejaarden een voorgeschreven dieet gebruiken (5). De belangrijkste diëten hierbij waren een natriumbeperking en een vetbeperking. De diëten werden voor het grootste deel gevolgd op advies van de huisarts of specialist. Daarnaast bleek dat $70 \%$ al meer dan 5 jaar het dieet volgden. De resultaten van het voedingsonderzoek bij de bejaarden in de stad Zutphen door Kromhout leverden een vergelijkbaar beeld op (6). In dit laatste onderzoek is tevens een vergelijking gemaakt met personen die geen dieet gebruikten.

Het verschil in natriumopname lussen personen die een natriumbeperkt dieet volgden en degenen die geen dieet gebruikten bedroeg slechts $300 \mathrm{mg}$ op een totaal van 2600 mg. Het ging hierbij alleen om hoeveelheden natrium die van nalure in de voeding aanwezig is of fabrieksmatig aan voedingsmiddelen is toegevoegd. Het aandeel dat uit de zoutpot bij de bereiding dan wel op tafel erbij gestrooid wordt, was in dit onderzoek niet meegenomen maar blijkt uit andere studies relatief gering te zijn: 15 a $20 \%$ (7). 
Wanneer we ervan uitgaan dat de bejaarden die een dieet houden überhaupt geen gebruik maken van de zoutpol dan zou de maximale winst van het dieet een vermindering met $750 \mathrm{mg}$ natrium zijn.

Wat leert ons dit praktijkvoorbeeld? Het natrium beperkte dieet wordt veelvuldig voorgeschreven bij de groep bejaarden. Over de keuze van het natriumbeperkte dieet in relatie tot de diagnose hypertensie zijn nog geen resultaten beschikbaar van deze twee studies. In het algemeen blijkt echter uit onderzoek dat er weinig systematiek zit in de therapiekeuze wanneer het volgen van een dieet wordt afgezet tegen medicamenteuze behandeling (8). Keren we terug naar onze grote groep bejaarden die zich meer of minder moeite hebben getroost om wat te doen aan de natriumopname.

Wanneer we de effectiviteit daarvan analyseren dan moet geconstateerd worden dat een daling in het natriumgebruik van $750 \mathrm{mg}$ bij een gemiddelde opname van 2 à $3 \mathrm{gr}$ een gering effect heeft op de bloeddruk. Vooral op oudere leeftijd dient er een forse reductie te zijn om nog enig effect op de bloeddruk kunnen waarnemen (9).

Slechts een drastische verandering in de voedselkeuze zal leiden tot een zodanige reductie in de natriumopame dat dit 
ook een effectieve daling van de bloeddruk tot gevolg heeft. Probleem is echter dat ongeveer de helft van de natriumopname wordt geleverd door de alledaagse producten brood, kaas, vleeswaren en soep. Het weglaten van deze producten of het gebruik van natrium-arme substituten, resulteert in een voedsel-pakket dat voor velen onacceptabel is, zowel qua samenstelling als smaak. Stel dat het mogelijk zou zijn om bij deze vier produktgroepen bij de industrièle bereiding $25 \%$ minder zout te gebruiken, zonder dat dit ten koste gaat van de smaak, dan kan de bejaarde met een natrium-beperkt dieet een totale reductie bereiken van 40 a $50 \%$, terwijl de bejaarde zonder dieet ca $20 \%$ minder natrium opneemt.

Het zal duidelijk zijn dat voor een effectief beleid in dit geval beide wegen bewandeld dienen te worden: dieetvoorlichting aan het individu en ontwikkeling van voedingsmiddelen met een verlaagd keukenzoutgehalte. Uiteraard speelt hierbij de voedingsmiddelenindustrie een essentiele rol. Allereerst dient deze ervan overtuigd te zijn dat er een afzetmarkt is voor dergelijke producten. De klant is in dit opzicht nog steeds koning.

Informatie over het dieet of voorlichting over gezonde voeding in het algemeen zal niet alleen de consument 
ontvankelijker maken maar indirect ook de voedingsmiddelenproducent omdat de vraag naar meer verantwoorde producten zal toenemen.

Er is echter nog een derde partij die een belangrijke rol speelt in dit proces, namelijk de overhelid. In het kader van de warenwet zijn voedingsmiddelenproducenten strikt gehouden aan minimale en maximale loevoegingen van ingredienten zoals keukenzout.

Een verruiming van de mogelijkheden voor het in de handel brengen van voedingsmiddelen met afwijkende receptuur zoals een verlaagd keukenzoutgehalte is daarom noodzakelijk.

Ook bestaat er nog de mogelijkheid een actief beleid in deze te voeren, nl. door dwingend op te treden via de warenwet waardoor verplichte veranderingen teweeg gebracht worden.

Tot op heden is de overheid erg terughoudend om zich in dit proces actief op te stellen. Slecthts de toevoeging van vit D aan margarine en hel joderen van broodzout zijn in dit verband te noemen. Als het om voedsel gaat spelen argumenten als zou de keuze vrijheid van de consument in het geding zijn, een grote rol. Zeker zal dit het geval zijn bij een overheid die deregulering hoog in het vaandel heeft. 
Toch is het een onderwerp dat een diepgaande discussie waard is. Het is dezelfde overheid die op een aantal andere terreinen niet schroomt om maatregelen te nemen ter bescherming van de volksgezondheid. Om tot een goede implementatie te komen van de eerder genoemde "Richtlijnen Goede Voeding" kan en mag de overheid niet langs de zijlijn staan om toe te zien hoe het proces tussen consumenten en levensmiddelen-fabrikanten zich zal ontwikkelen.

\section{Ondervoeding}

Het tweede voorbeeld komt uit de kliniek en gaat over de vraag of er überhaupt wel gesleuteld dient te worden aan de voeding.

Het is ontleend aan een onderzoek dat thans loopt in het Astmacentrum Hornerheide in samenwerking met de afdeling Pulmonologie, Heelkunde en Humane Biologie.

Het is een bekend gegeven dat patienten met chronische longproblemen zoals emphyseem in de loop van het ziekteproces veel gewicht verliezen (10). Dit verlies leidt er toe dat bij 40 a $50 \%$ van de patienten sprake is van ondervoeding, zich uitend in een extreem laag gewicht, verlies aan spiermassa en lage gehaltes aan circulerende 
eiwitten zoals albumine en pre-albumine. Door deze algehele verzwakking lopen deze patienten veel meer kans op een emstig acuut hart/long falen met daaraan gekoppeld een verhoogde sterftekans.

Alle reden om te kijken of een verbetering van de voedingstoestand leidt tot een verbetering van de gezondheidstoestand en meer specifiek van de longfunctie.

Over de oorzaak van deze vorm van ondervoeding is nog weinig bekend. Uit de eerste resultaten van het onderzoek blijkt dat het energieverbruik in rust bij deze patiënten sterk verhoogd is. Dit zou er op kunnen duiden dat de eiwitturnover verhoogd is in samenhang met een verlaagde spiereiwitsynthese en een verhoogde spiereiwitafbraak (11). Dit in tegenstelling tot de metabole veranderingen bij een gezond individu die vrijwillig vast, bij wie de eiwitturnover is verlaagd met als gevolg een verlaging van de ruststofwisseling met 20 à $30 \%$.

Het lijkt er dus op dat bij deze patienten een deregulering van het energie- en eiwitmetabolisme optreedt. Overigens een verschijnsel dat ook te zien is bij patiënten met kankercachexie (12). Anderzijds zijn er ook aanwijzingen dat door de continue strijd die geleverd dient te worden om zuurstof op te nemen er weinig tijd overblijft om rustig een 
maaltijd te gebruiken. Aldus zou er een neerwaartse spiraal ontstaan. De groeiende discrepantie tussen energieverbruik en -opname leidt tot prestatievermindering van de skeletspieren zich o.a. uitend in een verminderde contractiliteit. Dit laatste heeft weer tot gevolg dat de longfunctie verder achteruitgaat.

Het ligt dus voor de hand om te trachten om door middel van specifieke voedingsmaatregelen de voedingsstatus te verbeteren.

Toch is het de vraag of met de toevoer van extra energie de vicieuse cirkel doorbroken kan worden.

De ogenschijnlijke onaangepastheid van het energie- en eiwitmetabolisme kan ook berusten op een macabere aanpassing van het lichaam aan de ziekte. Een verhoging van het gewicht betekent automatisch een verhoging van de hoeveelheid actief weefsel in het bijzonder spierweefsel. Deze weefsels hebben zuurstof nodig om te functioneren en dat is nu juist het substraat waar continu een tekort aan is ten gevolge van de slecht functionerende longen. Een verbeterde voedingstoestand zal wel leiden tot een gedeeltelijke verbetering van de longfunctie, maar gezien het feit dat we te maken hebben met een ziektebeeld van irreversibele longweetselbeschadiging, is het maar de vraag 
of het een tegen het ander opweegt.

Dit laatste zou dus een reden kunnen zijn voor het merkwaardige metabool gedrag, om min of meer op een bestaansminimum te functioneren. De op het eerst gezicht logische stap om te starten met een energierijk dieet bij deze sterk vermagerde patienten zou mogelijk een averechts effect kunnen hebben. Een voorbeeld dat aangeeft dat gedegen onderzoek noodzakelijk is om na te gaan of onder deze omstandigheden een dieet effectief is.

\section{Overvoeding}

Het laatste voorbeeld is een afwijking waar velen frekwent aan sleutelen.

Het betreft de opstapeling van overtollige energie in de vorm van vetweefsel in ons lichaam ook wel overgewicht genoemd.

Alhoewel er verschillende methoden zijn om de hoeveelheid vetweefsel te kwantificeren is de zogenaamde Quetelet Index (Q) - gewicht (kg) gedeeld door lengte $(\mathrm{m})$ in het kwadraat - een eenvoudig te bepalen en toch redelijk betrouwbare maat.

Morbiditeit en mortaliteit nemen toe met toenemend 
gewicht. De Gezondheidsraad kwam enkele jaren geleden met de grens van een QI van 30 waarboven duidelijk sprake is van extra risico (13). Een Ql tussen 25 en 30 kan als een overgangsgebied beschouwd worden. Nemen we de grens van een Ql van 30 dan blijkt ca. $5 \%$ van de volwassen Nederlanders te lijden aan vetzucht. Hanteren we de grens van 25 dan neemt het aantal vetzuchtigen toe tot ongeveer $30 \%$. Deurenberg onderzocht de relatie tussen QI en huisartsenbezoek bij jong volwassenen (14). Het percentage mannen dat in het jaar voorafgaande aan het onderzoek een of meer keren de huisarts had bezocht, bedroeg voor diegenen met een Ql beneden de 25 - $45 \%$ terwijl bij mannen met een $\mathrm{Ql}$ groter dan 30 dit percentage ongeveer $60 \%$ bedroeg. Alle reden om uil een oogpunt van volksgezondheid aandacht te besteden aan dit probleem.

Dat er grote belangstelling is om er daadwerkelijk wat aan te doen, moge blijken uit cijfers over de toepassing van het z.g. broodwisseldieet. Een onderzoek door een marktanalysebureau een half jaar na de introductie leverde het ongelofelijke aantal van ruim 1 miljoen Nederlanders op die voor korte of langere tijd alternerend een dag op bruin brood hadden geleefd en een dag op normale voeding (15). 
Dat zijn er veel meer dan die om gezondheidsredenen iets aan hun gewicht zouden moeten doen. Dat bleek ook uit de resultaten van de groep vrijwilligers die zich bij onze vakgroep opgaven voor een onderzoek naar de effectiviteit van dit dieet. Ruim $40 \%$ had een al lager dan 27.

Dik is uit en Dun is in. De balans van het schoonheidsideaal ten tijde van Rubens is doorgeslagen naar de andere kant. Een graad van slankheid die evenzeer imaginair is voor de gemiddelde burger. Het is dan ook maar de vraag of gezondheid een belangrijk motief is om te gaan lijnen. Uit pragmatische overwegingen zou men kunnen stellen dat het ermee bezig zijn voldoende is ongeacht het motief. Of deze opvatting juist is beginnen steeds meer wetenschappers te betwijfelen.

Alvorens daar dieper op in te gaan wil ik eerst graag even stil staan bij de etiologie van overgewicht. Alhoewel de hoge prevalentiecijfers anders doen vermoeden, wordt het lichaamsgewicht zeer nauwkeurig gereguleerd. Honger en verzadiging zorgen ervoor dat afwijkingen tot een minimum beperkt blijven. Er zijn aanwijzingen dat in analogie met de bloedstolling een soort van cascadesysteem van neuropeptiden, die door de hypothalamus in de hersenstam worden geproduceerd, het hongergevoel meer of minder 
onderdrukken (16). Dit geeft een eerste grove regulatie op het niveau van energieopname. De fijne regulatie rondom een specifiek gewicht, het zgn. setpoint, lijkt vooral te geschieden door aanpassing in het energieverbruik (17). Het eerder genoemde fenomeen van een verlaging van het energieverbruik met 20 a $30 \%$ tijdens hongeren is daarvan een goed voorbeeld.

Over deze complexe regulatie en de mogelijke afwijkingen ervan weten we eigenlijk nog maar weinig. Uit o.a. tweelingen-onderzoek en onderzoek bij adoptiekinderen is bekend dat erfelijke aarileg een rol speelt bij het waargenomen fenomeen dat sommige individuën meer neigen naar hel accumuleren van lichaamsvet. Toch bestaat er wetenschappelijk weinig twijfel dat vooral de meer extreme vormen van overgewicht in de eerste plaats een gevolg is van een te hoge voedselopname al dan niet in combinatie met te weinig lichaamsbeweging (18).

Over de effectiviteit van een energie-beperkt dieet will ik kort zijn. Wanneer de energiebeperking strikt wordt gevolgd, is met grote zekerheid het gewichtsverlies te voorspellen ondanks allerlei verhalen in de lekenpers die het tegendeel beweren.

De echte problemen komen pas nadat men succesvol is 
afgevallen. De lange termijn prognose om dit bereikte gewicht te handhaven, is ronduit slecht. Slechts 10 a $20 \%$ is in dit opzicht succesvol (19).

Met recht kan dan ook gesproken worden van een postovergewicht syndroom. Uit steeds meer studies blijkt dat het lichaam een eenmaal verkregen status van overgewicht eveneens probeert te handhaven. Hel setpoint heeft zich ingesteld op een hoger niveau.

Zo is uit onderzoek binnen onze groep gebleken dat bij personen die ongeveer $15 \mathrm{~kg}$ waren afgevallen, 3 jaar nadien nog steeds een verlaging van de ruststofwisseling kan worden aangetoond. Uit dierexperimenteel werk blijkt verder dat herhaald vermageren en weer dikker worden, het zgn. jojo-effect, het lichaam steeds efficiënter maakt waardoor met minder energietoevoer het verhoogde gewichts-setpoint wordt gehandhaafd (20).

Alle reden om te voorkomen dat het zover komt. Het spreekt voor zich dat, wanneer we het hebben over preventie, de weg van de voorlichting om te komen tot betere eet- en leefgewoonten verreweg de belangrijkste is.

Matiging in de voedselopname in combinatie met een verhoging van de lichamelijke activiteit is in deze zonder twijfel zeer effectief. 
Kan de tweede strategie, de aanpassing van voedingsmiddelen in deze nog een belangrijke bijdrage leveren?

Het hoge vetgehalte van menig product lijkt hiervoor het eerst in aanmerking te komen. De industrie heeft op de groeiende behoefte van vetarme en dus energie-arme voedingsmiddelen ingespeeld met producten onder de verzamelnaam light. Producten als halfvolle melk, halvarine en grotendeels uit water en lucht bestaande sauzen zijn niet meer weg te denken uit het huidige voedingspatroon en leveren mogelijk een bijdrage aan de reductie van de vetopname. Men is zelfs nog verder gegaan en heeft suikervervangende stoffen zoals het aspartaam ontwikkeld, dat thans aan een snel groeiend aantal producten wordt toegevoegd. Tevens zijn een aantal ontwikkelingslaboratoria intensief bezig met de ontwikkeling van een vetvervanger op basis van polysucrose-ester of gemodificeerd eiwit. Wat dat betreft staan we nog maar aan het begin van een ontwikkeling waarvan het moeilijk te voorspellen is wat het eindresultaat zal zijn.

De overheid heeft in de afgelopen twee jaar een grootschalig onderzoek uitgevoerd naar de voedselconsumptie. De eerste resultaten zijn enkele maanden geleden gepubliceerd in het 
rapport "Wat eet Nederland?" (21). Met behulp van deze gegevens is het thans mogelijk na te gaan wat de bijdrage van deze aanpassinger is geweest en welke veranderingen er nog nagestreefd dienen te worden in de komende tijd.

Blijft nog een essentiële vraag over wanneer we het hebben over matiging van de energieopname, dit in tegenstelling tot bijvoorbeeld de verschuiving van opname aan verzadigd vet naar meer onverzadigd vet. In dit laatste geval is er geen fysiologisch regelmechanisme dat een dergelijke verschuiving teniet doet. In het geval van energie-arme producten t.o.v. de oorspronkelijk calorierijke producten kan het zo zijn dat extra opname van het light product het effect teniet kan doen. Helaas zijn op dit punt nog te weinig onderzoeksresultaten bekend om hierover een uitspraak te doen. Een betreurenswaardige situatie zeker in het licht van de vele claims die over allerlei light producten te beluisteren vallen. In erikele voedingsonderzoeken met het suikervervangend middel aspartaam bleek dat na een aanvankelijke daling van de energieopname het effect na 4 weken voor $80 \%$ teniet was gedaan door een grotere opname van de producten.(22). Lange termijn onderzoek is tot op heden niet verricht. 
Het is dan ook nog maar zeer de vraag of suikervervangende producten een belangrijke bijdrage kunnen leveren in relatie tot een energiebeperking. Alhoewel nog in een experimenteel stadium lijken de vetvervangers meer effectief te zijn. Ten eerste is het effect van de vervanging veel groter, gezien de grotere energiedichtheid en anderzijds blijkt het extra opname-effect vrijwel niet op te treden. Organoleptische problemen zouden hier overigens nog een belangrijke rol bij spelen.

Moeten we gelukkig zijn met deze hele "light-golf" die op ons afkomt? Ja en nee.

Ja, omdat het mogelijk zal zijn om in combinatie met een verandering in voedselkeuzegedrag te komen tot een reële reductie van de energieopname zonder dat hierbij de consument nu de indruk zal hebben dat een adequate voeding alle geneugten van het leven doet ontberen.

Nee, wanneer we zien dat de claim "light" vaak volkomen onterecht wordt gevoerd waarbij producten worden gepresenteerd die nog meer energie bevatten dan hetgeen ze vervangen. Een taak voor de overheid om via wetgeving aan deze vorm van misleiding wat te doen.

Eveneens nee, omdat er wel degelijk een reëel gevaar bestaat dat de balans doorslaat naar de andere kant. Het idee 
dat een gezonde voeding alleen nog maar haalbaar is met allerlei bijzondere producten is een reëel gevaar. Het Amerikaanse voorbeeld van de health food stores lijkt daarom een onvermijdelijk nevenverschijnsel wanneer het aspect gezondheid een belangrijker rol gaat spelen bij de voedselkeuze.

Toch blijf ik optimistisch dat de inspanningen die de voedingsvoorlichting zich reeds lange tijd getroost, in samenhang met een verantwoord productie-innovatiebeleid in de komende decennia hun vruchten zullen afwerpen. Verantwoord sleutelen aan veel producten zal ongetwijfeld leiden tot interessante en mogelijk verrassende verschuivingen in thet totale voedingspakket. Om eventueel sombere gedachten hierover te onderdrukken, wil ik u graag nog in herinnering brengen dat in 1970 er nauwelijks 10 jarige kinderen in Nederland te vinden waren met een gaaf gebit. Nu, ruim 15 jaar later na intensieve voorlichting over mondhygiëne, de introductie van fluortandpasta en de aanpassing van het snoep naar meer hard suikerwerk in plaats van plakkerige zachte snoepjes, heeft ongeveer $40 \%$ van de 10-jarigen nog een gaaf gebit (23). Wie had dat destijds durven voorspellen. Ook hierbij heeft de strategie van "maak de gezonde keus de gemakkelijkste keus" gewerkt. 


\section{Kader}

Het optreden van een deskundig kader om dit proces in allerlei geledingen adequaat te kunnen begeleiden is daarom van het grootste belang. In de medische opleidingen was de belangstelling voor voedingsonderwijs gering. Daarin is de laatste jaren veel verandering gekomen. Het belang van kennis omtrent de voedingstoestand van de patiënt wordt steeds meer op een lijn gesteld met andere aspecten van diagnostiek en therapie. Dit is ook te zien aan het groeiend aandeel artikelen over het onderwerp voeding in toonaangevende medische tijdschriften. In Nederland heeft de Stichting Voeding Nederland zich bijzonder ingespannen voor meer aandacht aan voedingsonderwijs, door in 7 van de 8 medische faculteiten bijzondere leerstoelen in te stellen op het gebied van de voeding. Door thans vanuit de eigen formatie aan dit vakgebied aandacht te schenken binnen zowel de opleiding geneeskunde als gezondheidswetenschappen neemt de $R L$ het voortouw binnen de Nederlandse universiteiten.

Uiteraard hangt dit nauw samen met de ontwikkeling van een zwaartepunt voeding binnen de onderzoeksorganisatie. Dit schept ook verplichtingen. Verwacht mag worden dat vooral 
op het gebied van de klinische voeding extra aandacht in het curriculum gegeven zal worden. Dit geldt niet alleen voor toekomstige huisartsen maar zeker ook binnen een aantal specialismen. In Amerika en Zweden is er een aparte opleiding "Klinische Voeding" voor artsen van verschillende disciplines. Of dat in Nederland ook haalbaar is, zal in de komende tijd onderzocht moeten worden. Daarnaast is het noodzakelijk dat er deskundigen in de voedingswetenschappen binnen de gezondheidszorgsector komen. Te denken valt hierbij aan onderzoek, onderwijs, voorlichting en beleid. Binnen de opleiding Gezondheidswetenschappen is in een aantal afstudeerrichtingen - in het bijzonder denk ik hierbij aan Biologische Gezondheidkunde - een accent gelegd op de klinische voeding. In de komende jaren dient dit verder uitgebouwd te worden. Vooral om hiermee een aanvulling te zijn op de universitaire opleiding Voeding in Wageningen waar het accent meer ligt op het voedsel en de voeding in het algemeen.

Tenslotte is er de opleiding Diëtetiek. De diëtist is bij uitstek degene die in samenspraak met de huisarts of specialist de patient voorlicht over aanpassingen in het voedingspatroon. Met de snelle ontwikkelingen vooral op het 
gebied van de klinische voeding - te denken valt hierbij aan het hele gebled van de sonde voeding en voeding per infuus worden hoge eisen gesteld aan de opleiding. Binnen het HBO heeft op dit gebied in de afgelopen vijf jaar dan ook een herorièntatie plaatsgevonden om op deze ontwikkelingen beter ingespeeld te zijn. In de totale heroriëntatie van het HBO en wetenschappelijk onderwijs zoals dit thans zijn beslag krijgt in de langzamerhand zo beruchte Harmonisatiewet, zijn er binnen de opleiding gezondheidswetenschappen ver gevorderde plannen om voor een aantal HBO opleidingen binnen de gezondheidszorg een verkorte 2-jarige wetenschappelijke opleiding aan te bieden in hel komende studiejaar. O.a. wordt hierbij gedacht aan een voortgezette opleiding voor diëtisten die zich op deze wijze verder kunnen bekwamen in vooral de wetenschappelijke aspecten van diëten. In de eerste plaats denik ik hierbij aan het onderzoek naar de effectiviteit van dieetvoorschriften.

Naast deze meer specifiek op de klinische voeding gerichte opleidingen is er een breed scala aan opleidingen die een ondersteunende rol kunnen vertolken om de aan voeding gerelateerde gezondheidsproblemen te attaqueren. 
I $k$ ben deze rede begonnen met de opmerking dat eten in de eerste plaats dient om gezond oud te worden.

De toenemende belangstelling bij de consument voor deze relatie heeft ertoe bijgedragen dat we driftig aan het sleutelen zijn geslagen om een aantal gezondheidsproblemen terug te dringen. I $k$ heb een aantal van de problemen geschetst die ons daarbij te wachten staan.

Om bij de terminologie van het sleutelen te blijven zou ik willen afsluiten met mijn vertrouwen uit te spreken dat we met een gezamenlijke inspanning deze klus klaren. 


\section{Dankwoord}

Aan het eind van een oratie mag men persoonlijk worden.

Ik wil die gelegenheid aangrijpen allen te bedanken die mij geholpen hebben het tot deze plaats te brengen.

Mijn interesse voor het vakgebied Voeding heb ik voor een groot deel te danken aan de vakgroep Humane Voeding, eerst onder leiding van professor Den Hartog, en later van professor Hautvast.

Waarde Den Hartog, beste Cees, als nestor van de voedingswetenschappen was het een voorrecht voor mij om jou als leermeester te hebben. Jouw brede visie op voeding was een solide fundament om op verder te bouwen.

Waarde Hautvast, beste Jo, van de vele wilde plannen die we in de korte Nijmeegse periode bedachten, heb je er vele ten uitvoer weten te brengen. Jouw enthousiasme en inzet om een klus te klaren hebben mij zeer geïnspireerd.

Waarde De Wijn, beste Frits. Je hebt voor mij een aantal deuren geopend om me verder te ontplooien. Misschien komt dat omdat we beiden sterk geïnteresseerd waren in de voedingsfysiologie. Mijn dank voor het vertrouwen dat je in me stelde.

Waarde Binkhorst, beste Rob. Jij bent mijn 
"Promotionsvater" en leermeester op het gebied van de inspanningsfysiologie. Ik grijp deze gelegenheid aan om je te bedanken voor de vele jaren van plezierige en wetenschappelijk leerzame samenwerking.

Waarde Ten Hoor, beste Foppe. De ontwikkeling van het vakgebied voeding binnen de $R L$ in de afgelopen vijf jaar is voor een belangrijk deel jouw werk. Je bood mij daarbij de gelegenheid me optimaal te ontplooien. Het tekent onze intensieve samenwerking en goede verstandhouding en dat geeft mij veel vertrouwen voor de toekomst.

Waarde leden van de vakgroep. De manier waarop jullie mij in deze nieuwe functie hebben verwelkomd deed mij veel deugd. Laten we op dezelfde wijze het werk samen voortzetten. 


\section{Literatuur}

1. Ross, MH. 1977

Dietary behavior and longevity.

Nutr.Rev. 35: 257-265.

2. Eaton SB, M. Konner 1985.

Paleolithic nutrition: a consideration of its nature and current implications.

New Engl.J.Med. 312: 283-289.

3. Voedingsraad 1986. Advies Richtlijnen Goede Voeding. Voeding 47: 159-181.

4. Saris WHM, MA v. Erp-Baart, F Brouns, KR Westerterp, $F$ ten Hoor. 1989.

Study on food intake and energy expenditure during extreme sustained exercise: the Tour de France. Int.J.Sport Med. 10, Suppl. 1.

5. Löwik MRH, Westenbrink S, Meulmeester JF el al. 1987.

Onderzoek naar de voeding en voedingsloestand van zelfstandig wonende mensen van 65-80 jaar.

Voeding 48: 177-191.

6. Kromhout D. 1989.

Voedselconsumptie en bloedlipiden bij zelfstandig 
wonende bejaarden.

In: Voeding van de oudere mens. Serie Voeding en Gezondheid. nr. 16, Samson Stafleu.

7. James WPT, A Ralph, CP Sanchez-Castillo. 1987.

The dominance of salt in manufactured food in the sodium intake of affluent societies.

Lancet I: 426-429.

8. Joossens JV, J Geboers 1983.

Salt and hypertension.

Prev.Med 12: 53-59.

9. Grobbe DE, A Hofman. 1986.

Does sodium restriction lower blood pressure.

Brit Med.J. 293: 27-29.

10. Hunter AMB, MA Carey, HW Lash. 1981.

The nutritional status of patients with chronic obstructive pulmonary disease.

Am.Rev.Respir.Dis 124: 376-381.

11. Goldstein SA, B Thomashowal, J Askanari

Functional changes during nutritional reptetion in patients with lung disease.

Clinics in chest medicine, 7: 1311-139.

12. Meyenfeldt M.F. von. Anorexia and cachexia in cancer. Proefschrift RL, Maastricht 1983. 
13. Gezondheidsraad 1984.

Advies inzake Adipositas.

Rapport no. 38 Gezondheidsraad Den Haag.

14. Deurenberg P, P van Poppel, JGAJ Hautvast. 1984.

Morbiditeit en subjectief welbevinden bij jonge volwassenen met overgewicht.

Ned.T. Geneesk. 128: 940-943.

15. Stichting Voorlichting Brood 1984.

Broodwisseldieet: heeft het zin of is het onzin. Een evaluatie. Den Haag.

16. Morley JS, AS Levine. 1983.

The centrale control of appetite.

Lancet I: $398-401$.

17. Keesey RE. 1986. A setpoint theory of obesity. In: Handbook of eating disorders. KD Brownell, JP Foreyt, Eds. New York, Basic books, pp. 63-87.

18. Jequier E, Y Schutz. 1985.

Does a deficit in energy metabolism contribute to human obesity?

In: Recent Advances in obesity. Ed. J. Hirsch, TB van Itallie.

John Libbey London, pp. 76-81.

19. Saris WHM. 1983. 
Prognose van het vermageren on lange termijn. Vergelijking van de verschillende therapievormen.

T.Gen.Ond. 8: 2075-2079.

20. Brownell KD, Greenwood MRC, E. Stellar, EE Shrager 1987.

The effects of repeated cycles of weight loss and regain in rats.

Physiol. Behav. 38: 459-464.

21. WVC 1988

Wat eet Nederland? Resultaten van de voedselconsumptie-peiling 1987-1988.

Distributiecentrum DOP Den Haag.

22. Itallie, $T$ van. 1984

Efficacy of low-caloric sweeteners in reducing food intake: studies with aspartame. In: Aspartame physiology and biochemistry. LD Stegink, LJ Filer, eds. M. Dekker Inc. NY, pp. 10-41.

23. Backer Dirks O, Kalsbeek H. 1987.

Vermindering van tandcariës in geïndustrialiseerde landen. NTVG 131: 1902-1907. 